\title{
ZDENĚK NEJEDLÝ A VÍTĚZSLAV NOVÁK. KE VZTAHU HUDEBNÍHO KRITIKA A SKLADATELE ${ }^{1}$
}

Při výzkumu hudební recepce (at' již je tento výzkum směřován $\mathrm{k}$ dílu samému, $\mathrm{k}$ tvưrčí osobnosti autora nebo šíře k určitému hudebnímu směru či stylu) náleží objasnění postojů, motivů a estetických hodnotících norem dobové hudební kritiky $\mathrm{k}$ důležitým faktorům, které mohou podstatnou měrou přispět $\mathrm{k}$ rekonstrukci „horizontu očekáváni'“2 tehdejšího publika a mohou rovněž poodhalit specifické rysy individuálního kritikova hodnotícího aktu. Hledáček naší studie se zaměří ke vztahu zakladatele české univerzitní hudební vědy, historika a muzikologa Zdeňka Nejedlého ke skladateli Vítězslavu Novákovi a jeho dílu. Ačkoli vzájemný poměr obou osobností nebyl dosud $\mathrm{v}$ odborné literatuře př́lišs reflektován, není vztah Nejedlého k Novákovi bezvýznamný. Vůdčí postava české hudební vědy a kritiky prvních dvou desetiletí 20. století se v něm střetává s „osovou osobností české moderní hudby“, jak Nováka v jedné ze svých studií přiléhavě charakterizoval muzikolog Jaroslav Volek. ${ }^{3}$ Po smrti Antonína Dvořáka roku 1904 se Vítězslav Novák postupně profiloval jako vůdčí osobnost české hudební moderny. Tím spíše nemohl vědec a kritik kalibru Nejedlého nechat ležet Novákovu tvorbu nepovšimnutu.

Rádi bychom zmínili i další aspekt, jenž zesiluje potřebu nahlédnout pod pokličku Nejedlého metodám vědecké práce a způsobům kritického posuzování. Přestože jsou některé Nejedlého názory s odstupem dneška právem vnímány jako problematické, často jednostranné, zapustila Nejedlého historická koncepce české hudby hluboké kořeny. Lze bez rozpaků říci, že prizmatem Nejedlého zčásti nahlížíme na českou hudbu také dnes. I po třiapadesáti letech od jeho smrti

1 Předložená práce vznikla za finanční podpory Ministerstva kultury v rámci institucionálního financování na dlouhodobý koncepční rozvoj výzkumné organizace Moravské zemské muzeum (DKRVO, MK000094862). Viz např. JAUSS, Hans Robert. Dějiny literatury jako výzva literární vědě. In Čtenár jako výzva: Výbor z praci kostnické školy recepčni estetiky. Brno: Host, 2001, s. 7-38. Jaroslav. Struktura a osobnosti hudby. Praha: Panton, 1988, s. 224-242. 
nevyslovujeme jména Bedřicha Smetany a Antonína Dvořáka jedním dechem, ale s př́ivažkem vzájemné polarity, hudbu Leoše Janáčka pak nezřídka vnímáme s reziduálním pocitem lidové primitivnosti atd. Jakou pozici na hodnotové ose Nejedlého zaujímal Vítězslav Novák, se pokusíme v předkládané studii zjistit.

\section{Zdeněk Nejedlý a kritika}

Kritika znamenala pro Nejedlého významnou, ba př́ímo integrální součást jeho hudebně vědecké činnosti. Relativně málo pozornosti bylo v novějších studiích věnováno v tomto ohledu vlivu F. X. Šaldy na Nejedlého hudebně kritické působení. Dle našeho názoru jde v tomto případě o vliv principiální. Šaldovo nové, ve své době převratné pojetí umělecké kritiky ${ }^{4}$ bylo pro Nejedlého důležitým impulsem k jeho vlastní kritické činnosti. Spojovalo se v jeho osobě s romantickým, národně obrozeneckým zaujetím, převzatým od milovaného Palackého, a inspiracemi, jež nalézal ve filozofických traktátech Friedricha Nietzscheho. Nejedlý ve svých kritikách doslova staví na odiv Šaldou požadovaný „vášnivý vztah a poměr k umění, poměr osobni a prožitý", je „násilníkem svého snu“, trpitelem, kritikem jednostranným, vášnivým, nespravedlivým a neobjektivním. „Každý velký kritik vylučuje naivně a nevéda mnohdy o tom, a priori, některé zjevy ze svého pochopeni nebo oceněni", píše Šalda. ${ }^{5}$ Čteme-li pasáže Šaldovy Kritiky pathosem a inspirací v Bojich o zitřek, vyvstává před námi postava hudebního kritika Nejedlého se všemi svými paradoxy a protiklady. Díky Šaldovým úvahám pro nás tak může být snáze pochopitelný fakt, že Nejedlý neusiloval př́lišs o objektivitu svých soudů. ${ }^{6}$ Byl apoštolem svého přesvědčení, které si zvolilo Bedřicha Smetanu za „neodmluvný, neodstranitelný, ničím nenahraditelný a tudiž nezrušitelný podklad české hudby ".7 Jako vědec, a zejména jako historik, se Nejedlý ztotožnil s romantismem 19. století a s českým národním obrozením, pro něž bylo př́značné spojení vědy a kulturní politiky - věda měla zároveň podávat morální apel určený budoucnosti. Charakteristická je v tomto smyslu Nejedlého adorace historika Františka Palackého. V podobném smyslu hovoří také Nejedlým obdivovaný Nietzsche ve svých úvahách o užitku a škodlivosti historie pro

4 Šalda formuloval své pojetí kritiky v př́slušném slovníkovém hesle v Ottově slovníku naučném roku 1900, posléze vyjádřil své názory zejména v knize Boje o zitřek: Meditace a rapsodie 1898-1904, publikované poprvé roku 1905.

5 ŠALDA, F. X. Boje o zitřek: Meditace a rapsodie 1898-1904. 6. vyd., Praha: Melantrich, 1948, s. 171.

6 JIRÁNEK, Jaroslav. Zdeněk Nejedlý - zakladatel české hudební vědy, In Z bojů o českou hudební kulturu. 1. vyd. Praha: Academia, 1979, s. 13-28. Jiránek zdůrazňuje, že estetické soudy Nejedlého byly založeny na Otakarem Hostinským postulované evidenci estetického soudu, který nepotřebuje být dále dokazován, protože je vždy soudem jedinečným. $Z$ toho následně vyplývá značný prostor pro libovůli hodnotícího subjektu.

7 NEJEDLÝ, Zdeněk. Zdenko Fibich: Zakladatel scénického melodramatu, Praha: Hejda \& Tuček, 1901, s. VI. 
život: Nietzscheovým ideálem byla monumentalistická historie - mýtická fikce, jež měla sloužit životu, současnosti i budoucnosti. Jeho kritika směřovala k pozitivistické historii, která chce „,šechno bráti objektivně, nad ničím se nezlobit, nic nemilovat, všechno pochopit“.

Tyto prameny se slévají v kritické činnosti Nejedlého a jeho žáků na stránkách hudebního listu Smetana založeného na podzim roku 1910. Společná idea, vyjádřená názvem časopisu, a proklamovaný cíl bojovat za myšlenku pokroku měly navázat na práci Otakara Hostinského a jeho boje o Smetanu. ${ }^{8}$ Hostinský předurčil Nejedlého vztah k české moderní hudbě, především co se týče poměru Smetana - Dvořák. Značné vyostření této polarity bylo však už především záležitostí Nejedlého. Balancování na hraně, které se mohlo lehce zvrtnout v kritikovu libovưli podmíněnou osobní záští či osobní náklonností, však Nejedlý ne vždy ustál.

\section{Vítězslav Novák očima Zdeňka Nejedlého}

V článku věnovaném roku 1920 Vitězslavu Novákovi k padesátým narozeninám v časopise Smetana se Nejedlý zmiňuje, že Nováka poznal již záhy po svém príichodu z Litomyšle do Prahy ve 2. polovině 90 . let 19. století: „Novák, s nímž jsem se tehdy seznámil, když zvěděl, že studuji u Fibicha komposici, ihned projevil zájem dokonce i o mé »skladby", ač jsem byl venkovský zajic, který se v Praze sotva okoukl. Vim také ještě dnes, jak to na mne tehdy silně působilo." Zde je patrně nutno hledat počátek Nejedlého vztahu k Vítězslavu Novákovi, který byl pravděpodobně silně motivován osobními sympatiemi. Velmi přijatelným se zdá názor kolektivu autorů nepublikované monografie o Zdeňku Nejedlém, jež vznikla na půdě Ústavu pro českou a světovou literaturu ČSAV v 80. letech 20. století pod vedením historika Petra Čorneje: „Novák Nejedlému imponoval jako umělec i jako člověk. Imponovalo mu jeho bytostné bouřliváctví i jeho činorodost a zájem o mladé a jejich výchovu (Novák náležel k nejlepším učitelům kompozice $v$ dějinách české hudby). Imponoval mu i jako neohrožený průkopník české hudební moderny, neohližejíci se napravo ani nalevo, pokud byl presvědčen o své umělecké pravdě “" Přestože Novák byl žákem Dvořákovým, nesdílel osud Josefa Suka a Oskara Nedbala, jejichž dílo Nejedlého strana ostentativně ignorovala.

Novákově skladatelské činnosti věnoval Zdeněk Nejedlý do roku 1918 soustavnou pozornost ve svých četných článcích v novinovém i časopiseckém tisku a dotkl se letmo Novákovy osobnosti také ve svých raných knižních monografí́ch Zdenko Fibich. Zakladatel scénického melodramatu (Praha 1901) a Dějiny české hudby (Praha 1903). Nelze na tomto místě nezmínit Nejedlého pokus o ucelené uchopení Novákovy tvorby v sérii článků uveřejňovaných v letech 1910

8 Úvodem. Smetana, 1910/11, roč. 1, č. 1, s. [1]. Dále: HELFERT, Vladimír. Hudební věda a naše hudební poměry. Smetana, 1910/11, roč. 1, č. 1, s. 4-5; BARTOŠ, Josef. F. X. Šalda a snahy mladé české hudební kritiky. Smetana, 1913/14, roč. 4, č. 1, s. 5-9. Citováno dle KŘESŤAN, Jiří. Zdeněk Nejedlý: Politik a vědec v osamění, Praha 2012. 
a 1913-1914 na stránkách hudebního časopisu Smetana. Souhrnně a v nezměněné podobě pak byla tato Nejedlého rozsáhlejší studie vydána roku 1915, doplněná o další vývojová stadia Novákovy tvorby a o výběr Nejedlého novákovských kritik vyšla posléze ještě roku $1921 .{ }^{10}$ Metodologii této práce, sumarizující Nejedlého názory na Novákovo skladatelské umění, se budeme věnovat podrobněji níže.

Přikročme však nyní k samotným Nejedlého kritickým soudům týkajícím se Nováka. Byt' Nejedlý Nováka zprvu vnímal jako konzervativce, byl pro něj nejlepším z Dvořákových žáků, který se postupně začínal přiklánět k programní hudbě. Právě programnost (v duchu Smetanově) byla zprvu pro Nejedlého jedním z významných př́iznakủ hudební pokrokovosti. Ve své fibichovské monografii z roku 1901 se o Novákovi zmiňuje v kapitole nazvané Fibich a mladá česká hudba následujícími slovy:

„[...] Suk a Novák jsou žáci Dvořákovi, zajímavo však jest jich přeskakování $v$ hudbu programní. Kde pak objeví se na této půdě moderni, citite ihned, jak na ně pưsobi ovzduši Fibichovo. [...] Novák podobně v ouvertuře $k$,"Maryši “ nebo v balladách pianových jakožto hudbě programni přestává být Dvořákovcem." $" 11$

V Dějinách české hudby pak v kapitole Mladí konservativci zaznívá z pera Nejedlého již rozsáhlejší i názorově vyhrocenější stanovisko:

„Vitězslav Novák jest nejlepši skladatel Dvořákovy školy. [...] Vyšel z neobmezeného zbožňováni Brahmse a Dvořáka. V tomto ovzduši napsal houslovou sonatu, trio, některé drobné skladby klavirní (vydány u Simrocka) a písnè. Novák však vyznačuje se vážností, hloubavostí pravého umělce a snahou po novém, že nemohl se tu cítit štastným. Chtěl se dostat z těchto vlivů stupňováním zásad Dvorákovy hudby do poslednich konsekvencí. Uznávaje rhytmus za hlavní hudebni princip, žrekl se vědomě a dobrovolně melodie, pro niž měl smysl velmi vyvinutý. Stotožniv pak též národnost hudby s požadavky uměleckými, vyvolil si Slovensko (moravské Valašsko), kde hodlal najíti novou národní individualitu. Odtud vznikly jeho skladby, jež bychom mohli nazvat nemelodické a slovenské. Jsou to „Moravské pisničky“, ballady pro smíšený sbor , Vražedný mily' “ a „Neščasná vojna“, klavirni kvintett, „,Moravské tance“ pro klavír, z orkestrálních ouvertura $k$ „,Maryše “ a symfonický obraz „, V Tatrách". Tímto extremem však privedl celý směr ad absurdum a v tom spočivá jeho význam historický. Zdá se, že to pocitil sám a že jeho písně „Melancholie“, sice pod vlivem Brahmsových písní, avšak spějicí za zcela jiným cílem, moderním, jakož $i$ balladové trio g-moll znamenaji nový obrat v tvořeni jeho." ${ }^{2}$

10 NEJEDLÝ, Zdeněk. Vitězslav Novák: Část první, Praha: nákladem časopisu „Smetana“, 1915, 66 s.; NEJEDLÝ, Zdeněk. Vitězslav Novák: Studie a kritiky, Praha: Melantrich, 1921, $239 \mathrm{~s}$.

11 NEJEDLÝ, Zdeněk. Zdenko Fibich: Zakladatel scénického melodramatu, Praha: Hejda \& Tuček, 1901, s. 177-178.

12 NEJEDLÝ, Zdeněk. Dějiny české hudby. V Praze: Hejda \& Tuček, s. a. [1903], s. 248-249. 
Tímto obratem v Novákově tvorbě měl být př́íklon k subjektivismu, jenž stál v měrítku Nejedlého uměleckých hodnot na jedné z nejvyšších prríček. I z tohoto důvodu Nejedlý pozorně sledoval také v následujících letech Novákovu slibnou skladatelskou kariéru, jeho úspěchy a sílící postavení na poli české moderní hudby a Novákova nově vznikající díla hodnotil vesměs s nadšením. Po provedení Novákovy symfonické básně $V$ Tatrách psal ve své kritice z 12. prosince 1907 do deníku Den, že ,zde Novák probral se již úplně ze svého někdejšího ovzduši a vyrůstá v nové světy, v nichž každý ctitel hlubokého umění bude ho provázeti s obdivem i radostí. I Nováka spasilo to slovo, jež bylo nejprve u Boha! Jím promlouvá k nám ne pouhý kombinovatel akordiu, nýbrž duch moderní, v němž myšlenka proniká vše, i nejniternějši propasti citové. “13 Ještě tentýž měsíc Nejedlý uveřejnil na stránkách téhož listu krátkou kritickou studii věnovanou Novákovu stylovému vývoji a obecným rysům jeho tvorby. ${ }^{14}$ Novákův současný pokrok spočívá podle Nejedlého v tom, že „,nehledá svéráznost umění podle starého programu v něčem mimo sebe, nýbrž zcela moderním způsobem nalézá ji v sobě samém“. Zastaralý program konzervativní strany závisel podle Nejedlého na hesle: „,budovati z prostředků lidového uměni naše velké národní uměni" $i^{\prime \prime}{ }^{15}$ Podobně v dubnu roku 1908 reflektoval Nejedlý pražskou premiéru Novákova Tomana a lesní panny: „Novák, kdysi odpůrce ,programni “ hudby, dnes vplul zcela v tento moderni směr. [...] Novák však četbou sám přišel a musil přijíti k poznání, že hudba müže, a dnes vlastně pro moderního skeptického člověka musí míti jiný účel než býti sebekrásnějšim , klinkáním“. V symfonické básni „O věčné touze“ "zpivá svou niternou písen̆, mnoho vyjadřující ze všeobecné nálady moderního člověka. $V$ „Tomanu“ “jde Novák ještě dále a po prvé uživá i literárního programu za podklad své skladby." "16 Svůj kritický názor na osobnost a tvorbu Vítězslava Nováka Nejedlý ještě prohloubil roku 1909 v rozsáhlém úvaze věnované II. smyčcovému kvartetu, op. $35 .{ }^{17}$ Poukazuje znovu detailněji na skladatelovo rané období, jeho konzervativismus závislý na Dvořákovi a Brahmsovi, na omyly Novákovy „moravsko-slovenské periody“. V Novákových současných dílech vyzdvihuje podíl subjektivnosti, přičemž velice zajímavý je v této souvislosti Nejedlého poukaz na vzájemnou korespondenci estetické hodnoty kritizovaného díla a etické hodnoty osobnosti jeho tvůrce: „Jeho kvartet op. 35 má mnoho beethovenského

13 NEJEDLÝ, Zdeněk. Druhý koncert Orchestrální jednoty. In NEJEDLÝ, Zdeněk. Kritiky: (Den 1907-1909). 1. vyd. SNKLHU. Praha: Státní nakladatelství krásné literatury, hudby a umění, 1954, s. 108.

14 NEJEDLÝ, Zdeněk. Vitězslav Novák. In NEJEDLÝ, Zdeněk. Kritiky: (Den 1907-1909). 1. vyd. SNKLHU. Praha: Státní nakladatelství krásné literatury, hudby a umění, 1954, s. $120-122$. Ibid., s. 121.

16 NEJEDLÝ, Zdeněk. Kovařovicưv koncert. In NEJEDLÝ, Zdeněk. Kritiky: (Den 1907-1909). 1. vyd. SNKLHU. Praha: Státní nakladatelství krásné literatury, hudby a umění, 1954, s. 226.

17 NEJEDLÝ, Zdeněk. Vitězslav Novák: Kvartet op. 35. In NEJEDLÝ, Zdeněk. Kritiky: (Den 1907-1909). 1. vyd. SNKLHU. Praha: Státní nakladatelství krásné literatury, hudby a umění, 1954, s. 439-444. 
v sobě, čímž neminím nějaké napodobení, avšak i u Nováka cítíme stále, že k nám nemluvi hudebnik, jenž nám chce ukázati krásné melodie a harmonické spoje, nýbrž člověk, jenž nám chce sděliti více než všechny tóny světa, totiž sama sebe. Celý kvartet pak ukazuje hodnotu této bytosti, jež se nám tu dává." "18 Roku 1910 píše Nejedlý nadšený referát po brněnské premiéře Bouře ${ }^{19}$ a zmíněné dílo hodnotí jako „nejvelkolepějši symfonii, jež byla u nás napsána“ a velice kladně se vyjadřuje i o prvním provedení úryvků z klavírního Pana na počátku roku 1911. ${ }^{20}$

\section{Osobní spory}

Po premiéře Novákovy Boure, díle, které tehdy určitě vnímal jako jeden z vrcholů české moderní hudby, začal Nejedlý skicovat svůj ,první pokus o shrnutí svých predstav o uměni Novákově", jejž na pokračování uveřejňoval na stránkách časopisu Smetana od listopadu do prosince 1910. K Nejedlého cti slouží, že jeho vydávání nezastavil ani po uveřejnění protestního dopisu dvořákovcủ v Národnich listech $\mathrm{v}$ prosinci 1912 (Vítězslav Novák taktéž připojil svůj podpis) ${ }^{21}$, a ve své studii pokračoval dále od záŕí 1913 do března roku 1914.

Novákův podpis pod protestním prohlášením na obranu Antonína Dvořáka nemohl nenechat Nejedlého chladným. Ve své odpovědi na stránkách hudebního listu Smetana analyzoval personálie podepsaných osob a několik řádků při tom věnoval i Novákovi: „Na misto zcela zvláštni kladu Vitězslava Nováka, jenž protest také podepsal, ač jeho názory o Dvoř́kově tvorbě jsou dobře známy. Mysleme si však, že to udělal z piety žáka k učiteli. Překvapeni však tu nejsou vyloučena, proto zatím - - - - - - - - - - “22 Sám Novák se o pohnutkách k činu připojit svůj podpis pod protest iniciovaný hudebníky kolem časopisu $\mathrm{Hu}$ debni revue a okruhem přátel Josefa Suka zmiňuje krátce ve druhém díle svých pamětí: „I přihodilo se, že někdy na sklonku roku 1912 večeřeli v naši hudební domácnosti dva dirigenti mé Bouře v té sezóně, dr. Vilém Zemánek a Jaroslav Křčcka. A tu se pojednou prvý z nich vytasil s posledním čislem Smetany, upozorňuje na nešetrný tón, v jakém tam bylo psáno o Antonínu Dvoŕákovi. Dle jeho mínéni mělo se veřejným prohlášením protestovat proti neobvyklému dosud u nás zpưsobu kritiky. Toto počináni pokládal jsem za bezúčelné, ale bylo na mne naléháno, abych zahájil tuto akci [...]. Chtě nechtě musil jsem se podvolit. Protest uveřejněn, veřejnost zajímal sice tuze málo, vyvolal však dalš́ polemiku, v niž o hudbu nikdy se nezajímající F. X. Šalda nazval nás štěkajicí smečkou. “23 Možno tvrdit, že Vítězslav Novák nenalezl pro Nejedlého nikdy pochopení. Kupř́kladu

18 Ibid., s. 443.

19 NEJEDLÝ, Zdeněk. Bouře. Hlidka Času, 1910, roč. 5, č. 17.

20 NEJEDLÝ, Zdeněk. Novákův „Pan“. Smetana, 1910/11, roč. 1, č. 9, s. 143-144.

21 Protest. Národní listy, 1912, roč. 52, č. 346 (15. 12. 1912), s. 4.

22 NEJEDLÝ, Zdeněk. Boj o Dvořáka: II. Personalie. Smetana, 1912/13, roč. 3, č. 9-10, s. 104.

23 NOVÁK, Vítězslav. O sobě a o jiných. 1. vyd. Praha: Editio Supraphon, 1970, s. 199-200. 
o Nejedlého Hudebním klubu se v dopise Rudolfu Reissigovi z 15. února 1912 (tedy ještě před vlastním vypuknutím bojů o Dvořáka) vyslovil jako o „,klubu hudebních břídilu““, kteří s prof. Zdeňkem Nejedlým v čele, tvoří „,hnusnou skvrnu $v$ našem hudebním životě ${ }^{24}$. Jejich projevy jsou podle Nováka hulvátské, takže $\mathrm{s}$ těmito pány je osobní styk vyloučen. Je na místě poznamenat, že $\mathrm{v}$ tom sdílel Novák svůj postoj např. s Leošem Janáčkem, který o Nejedlém uveřejnil v časopise Hlídka fejeton s názvem Letnice 1910 v Praze, v němž s břitkým humorem, jemu vlastním, kritizoval Nejedlého přednášku v rámci cyklu Česká zpěvohra po Smetanovi. ${ }^{25}$ Janáček ve svém fejetonu postřehl, že Nejedlého přednáška se vyznačovala „Zamlklostí hudebni““: „Všimněme si např. prívalu slovního, kterým mluví o veledílech Bedřicha Smetany. Co v něm hudebního jmenuje? Jaký je to součet hudebního myšleni?"“, ptá se. Nejednou byl Nejedlý obviněn z mezerovitosti v hudebně teoretickém vzdělání. Tento nedostatek mu vyčítali zejména skladatelé a praktičtí hudebníci. Např. Ladislav Vycpálek odhalil Nejedlého handicap ve stati Jak se pan prof. Nejedlý učil harmonii. ${ }^{26}$ Ale i Vítězslav Novák se roku 1911 dostal s Nejedlým do sporu kvůli jeho kritice provedení Balladového tria na koncertě Pražské konzervatoře. ${ }^{27} \mathrm{Na}$ stránkách Hudební revue se Novák ohradil proti Nejedlého nešetrnému soudu pronesenému na účet Českého tria: „Poněvadž skladba ta byla studována dle mých pokynů a provedena presně v mých intencich, citím se bagatellisujicími slovy prof. Nejedlého rovněž dotčen a ohrazuji se proti jeho zřejmě predpojaté kritice. " ${ }^{28}$ Nejedlý se ve své následující odpovědi elegantně vyhnul př́mému střetu a bystře odhadnul i negativní povahové rysy některých Novákových přátel, jež se naplno projevily o dva roky později v tzv. „bojích o Dvořáka“: „Vitězslav Novák učinil své prohlášení zajisté z pohnutek nejčestnějšich: na obranu svých přátel. Tito by však měli vědět, že jim žádné prohlášeni nepomůže, nedovedou-li zvitěziti svým vlastním uměleckým pưsobením. Mistr však jako jest Novák, měl by býti i jeho blizkému okolí osobou povznesenou nad titěrné jich zájmy a jeho př́mé, odhodlané povahy nemèlo by býti zneuživáno takovýmto způsobem. Na žurnalistické pletichy stači jiné síly z Novákova okoli, které nemaji jiných schopností. “29

Další významný spor mezi oběma umělci vyvolala premiéra Novákových Svatebních košil 3. prosince 1913 v Praze. Je otázkou spekulace, co dalo př́činu tak ostré a negativní kritice z pera Zdeňka Nejedlého, zda šlo o skutečný vnitřní

24 Dopis uložen v Českém muzeu hudby v pozůstalosti Vítězslava Nováka, sign. S 143/221.

25 JANÁČEK, Leoš. Letnice 1910 v Praze. Hlídka, 1910, roč. 27, s. 555-560, 640-644. Viz rovněž FUKAČ, Jiř́i. Leoš Janáček a Zdeněk Nejedlý (K problematice vztahu české kritiky k tvorbě počátku 20. století). In Sborník praci filosofické fakulty Brněnské university, 1963.

VYCPÁLEK, Ladislav. Jak se pan prof. Nejedlý učil harmonii. Hudební revue, 1911, roč. 4, č. 7, s. 379-380.

NEJEDLÝ, Zdeněk. Jubilejní koncerty konservatoře. Smetana, 1910/11, roč. 1, č. 17-18,s. 271-275.

NOVÁK, Vítězslav. Z hudebního života. Hudební revue, 1911, roč. 4, č. 7, s. 396.

29 NEJEDLÝ, Zdeněk. Z hudebního života: Vítězslav Novák. Smetana, 1911/12, roč. 2, č. 1, s. $15-16$. 
nesouhlas s Novákovým dílem, či za jeho odmítnutím stála osobní zášt’ vyvolaná Novákovým podpisem v otevřeném dopisu českých hudebníků proti hanobení Antonína Dvořáka Nejedlým a jeho žáky. V Nejedlého kritice byl Svatebním košilím vytknut nedostatek dramatičnosti, především však naturalismus, pouhé primitivní podmalovávání slov. Nechtěně k takovému soudu přispěl i sám Novák, který před premiérou uveřejnil v Hudební revue podrobný rozbor svého díla, v němž upozorňoval na zvukomalebné detaily své kantáty. ${ }^{30}$ Následovala obdobná kritika Vladimíra Helferta Konce hudebního naturalismu, uveřejněná v České kultuř ${ }^{31} \mathrm{~K}$ Nejedlého a Helfertovu stanovisku se tentokráte přidala i řada Novákových přátel (mj. Václav Štěpán), což se Vítězslava Nováka nepř́ijemně dotklo. ${ }^{32}$ Podobný charakter měly i Nejedlého odsudky Novákových oper Zvíkovský rarášek a Karlštejn v následujících letech. ${ }^{33}$ Novákův poměr k operní dramatické tvorbě je podle Nejedlého pochybený již v samých základech - ,je př́liš vnější, ne vnitřni". Nejedlý vytýká Novákovi pouhou ilustrativnost, at' již je založena na zvukomalbě či na příznačných motivech. Nazývá Nováka „deskriptivním hudebnikem, jenž bére myšlenku ze své textové předlohy a svou hudbou ji jen komentuje“ “ ${ }^{34}$ Tím je dle Nejedlého znemožněn i všechen vnitřní hudební vývoj, jenž je ,kořenem hudebni dramatičnosti ${ }^{\text {“ }}{ }^{35}$ Svůj kritický náhled na Novákovu tvorbu završil Nejedlý ve své studii $K$ revisi hudebního impressionismu, ${ }^{36} \mathrm{v}$ níž naprosto obrací svůj někdejší názor na skladatelovu symfonickou báseň Toman a lesní panna: „Toman jest vytvořen z téhož materialu, týmž stilem i touž manýrou jako ona díla ryze naturalistická, takže musíme je posuzovati jako jeden typ, a to typ naturalistický, nebot' jest jisto, že postavime-li Tomana vedle Svatebnich košil, nestanou se nám Svatební košile méně naturalistické, za to však tím zjevněji vyniknou nám naturalistické prvky $v$ Tomanu. “37

\section{K metodologii Nejedlého vědecké a kritické činnosti}

Zastavme se nyní u metody Nejedlého vědecké práce a kritického hodnocení. Poznání Nejedlého východisek a na ně navazující metodologie je důležité pro

30 NOVÁK, Vítězslav. Svatební košile. Hudební revue, 1913/14, roč. 7, č. 2, s. 61-67.

31 HELFERT, Vladimír. Konce hudebního naturalismu: (Vítězslava Nováka Svatební košile). Česká kultura: Kritický list umělecký a vědecký, 1913/14, roč. 2, č. 6, s. 97-100.

32 NOVÁK, Vítězslav. O sobě a o jiných. 1. vyd. Praha: Editio Supraphon, 1970, s. 206.

33 NEJEDLÝ, Zdeněk. Vitězslava Nováka „Zviḱkovský rarášek“. Smetana, 1915/16, roč. 6, č. 1, s. 1-5; NEJEDLÝ, Zdeněk. Vitězslava Nováka „,Karlštejn “. V Praze: Nákladem časopisu „Smetana“, 1916.

34 NEJEDLÝ, Zdeněk. Vitězslava Nováka „Karlštejn“. V Praze: Nákladem časopisu „Smetana“, 1916, s. 27.

35 Ibid., s. 28.

36 NEJEDLÝ, Zdeněk. K revisi hudebního impressionismu. Smetana, 1915/16, roč. 6, č. 9-10, s. $130-136$.

37 Ibid., s. 134. 
možnost zhodnocení Nejedlého soudů jak o Novákovi, tak i o jiných osobnostech, jimž věnoval svůj zájem. ${ }^{38}$ Je úkolem současné muzikologie vypořádat se $\mathrm{s}$ osobností Zdeňka Nejedlého. Jeho závěry však neleze přijímat nekriticky. Je třeba získat přehled o Nejedlého metodě, s jejíž pomocí vznikaly jeho práce vědecké, jednak o jeho metodě hudebně kritické. Nutno poznamenat, že obě tyto oblasti se v Nejedlého tvorbě značně prolínají, ba možno říci, že tvoří nerozlučný a vzájemně se podmiňující celek. Toho je př́kladem rovněž Nejedlého monografie o Novákovi, jež v sobě spojuje snahu proniknout k psychologickému jádru skladatelovy osobnosti a tvorby.

Analyzujeme-li Nejedlého kritické výroky o Novákovi, zaujme především Nejedlého vyzdvihování uměleckého subjektivismu na jedné straně a zavrhování faktorů vnějších (objektivních), na straně druhé (principiální odmítnutí budování národní hudby na podkladu hudby lidové, odmítnutí naturalismu, zvukomalby a ilustrativnosti). Uvedený protiklad subjektivního a objektivního se vine Nejedlého kritickou činností prvních dvou desetiletích 20. století jako červená nit. $\mathrm{Na}$ jeho základě si lze vysvětlit např. Nejedlého ostrou kritiku francouzského impresionismu i italského verismu, jejichž skladatele vinil z př́lišné povrchnosti a vnějškovosti. Opačně lze tímto způsobem pochopit i jeho kult wagnerovský a mahlerovský.

Speciální hudebně vědeckou metodologií se Nejedlý na stránkách svých spisů nikdy prŕliš nezabýval a způsob své práce spíše naznačoval. Metodologickou nedůslednost Nejedlého kritizoval zpětně mj. Vladimír Helfert $\mathrm{v}$ jednom z dopisů Mirko Očadlíkovi: „To, co pišete o svých zkušenostech s autorem nedokončitelného Smetany, mne pranic nepřekvapuje. Tohle mi bylo zřejmé už dávno a hovorívali jsme o tom často s Zichem. Vite sám, co je pro lidské síly dosažitelné při pilné tvořivé práci. Délá-li se něco nad to, musí se ukázat výsledek. To je prostě přirodní zákon, který se nedá obejít. Dělat zároveñ několik velkých věci najednou, neni možno. Mne však při tom nejvice vadil nedostatek pevné metodičnosti. To se jeví v celkovém rozvrhu i $v$ detailu. Je to konec konců nedostatek vlastni ukázněnosti. A to máte marné: at’ to zní sebe ,kantorštěji “, stále nutno to připominat: bez př́sné ukázněnosti není velké a cenné práce. Právě na Smetanovi já obdivuju tu jeho úžasnou vnitřni kázeň, kterou dovedl spojit se svým geniálním rozletem. A to je tak všude. Tohle se mu nikdy a nikde nedostávalo a $v$ tom bude vždy tragika jeho spisovatelského a vědeckého připadu. Nic není platno, člověk $v$ rozhodných chvilich musi mít odvahu určité věci, které by snad vedly $k$ okamži-

38 Z hlediska historického, estetického i muzikologického je problematice metodologie Nejedlého vědeckých prací věnována až překvapivá řada novějších, často detailních studií: RACEK, Jan. O hudebně-vědecké metodě Zd. Nejedlého. Index, 1929, č. 6, s. 7, č. 7, s. 7; ČERNÝ, Miroslav K.: Historismus a Nejedlého koncepce muzikologie. Hudební véda, 1977, roč. 14, č. 1, s. 52-71; HANZAL, Josef: Vědecká metoda a umělecké tvůrčí postupy v českém dějepisectví, In Zdeněk Nejedlý: Doba-život - dilo, Praha: Ústav pro českou a světovou literaturu ČSAV, 1975, s. 35-69; STŘÍTECKÝ, Jaroslav - HANZAL, Josef: Předmluva, In NEJEDLÝ, Zdeněk: Uměni staré a nové. Výbor ze studií, Praha: Editio Supraphon 1978, s. 5-37; JIRÁNEK, Jaroslav: Zdeněk Nejedlý - zakladatel české hudební vědy, In $Z$ bojů o českou hudebni kulturu. 1. vyd. Praha: Academia, 1979, s. 13-28. 
tému úspěchu nebo k okamžité zálibě, prostě potlačit. Je to často bolestné, ale ono se to pak nahradi jinde, na té hlavni práci. A nakonec právě tohle bývá pramenem pravého štěstí. Probatum est! Proto vždy zdůrazňuju nutnost prísné metodičnosti $v$ musikologii, nebot' tato metodičnost je mi věci oné životni sebekázně jako cestě k trvalým hodnotám duchovním.“"39

Jak již konstatovali mnozí, ${ }^{40}$ převážily u Nejedlého metody obecně historické nad speciálními metodami muzikologickými (konkrétně hudebně analytickými). Sám se označoval za historika hudby, ostatně předmětem Nejedlého zájmu nebyly hudební kompozice samy o sobě, jejich struktura, ale osobnost tvůrce, psychologie jeho díla. O tom svědčí jeho Richard Wagner, Gustav Mahler i Vitězslav Novák. Přes pozdější ostrou kritiku Nejedlého muzikologické produkce, je však nutno zdůraznit, že Nejedlý byl metodologicky plně na výši své doby, v níž se metody a postupy hudebně vědecké práce teprve formovaly. Neprrímo lze u Nejedlého vystopovat zejména vlivy Wilhelma Diltheye, jeho tezi o prvořadém místě biografie $v$ historii a přsesvědčení, že historik musí uplatňovat vedle klasických postupů také vcítění, intuici a introspekci. Historické faktum (událost) může být vřazena do širších souvislostí pouze na základě jejího intuitivního znovuprožití. Tyto postupy Nejedlý rád využíval ve svých uměleckých monografí́ch a rovněž v monografii Novákově, kde pracuje s rekonstrukcí psychických a duševních prožitků a stavů skladatele. Nejedlého pronikání k podstatě hudebních skladeb bylo založeno na vcítění, což jej přibližuje k tzv. Einfühlungsästhetik a k hermeneutice Hermanna Kretzschmara. Také proto jsou Nejedlého vývody přesvědčivější u děl programních či s textem. Svou konfesi, jíž se řídil i ve svých novákovských studiích, formuloval Nejedlý v úvodu ke svému Gustavu Mahlerovi: „Nejen umění, nýbrž $i$ věda jest podmíněna tvořivostí ducha, dokonce pak již věda, jejímž úkolem jest tvořiti lidské individuality. Zde vědecká analysa jest nutný prostředek, nikdy však cíl práce. Vědecká solidnost prokáže se ovšem solidností metody, kritisujici každý detail a stanovici si pevně materiál, z něhož možno stavěti. Ale stavba sama žádá pak více než jen solidnost, má-li to býti stavba, jež má svưj vzlet $i$ svou hloubku. Zde nutno tvořiti, stejně jako v umění. Vnímati umělecké dílo jest jen jiný zpưsob tvoření, totiž spolutvoření v duchu prvního tvi̊rce. Čím lépe umělecké dílo vnímám, tím více přibližuji se umělecky tomu, jenž je tvořil. Vnímati celého umělce, jest pak zase jen dalši stupeñ této uměleckosti. Jen tak může vzniknout celistvá postava umělce, evokovaná tvořivou prací z materiálu kriticky zjištěného. [...] Teprve ten, kdo dovede se státi subjektivní, kdo dovede proniknout v nitro umělcovy duše, tam se napojiti vznětem a nadšením a jím pak posuzovati jeho činy, teprve ten je objektivni ve vyššim dobrém smyslu, nebot'odhaluje tajemné světy v jich pravé podobě, [...] objektivisuje nejvznešenější práci lidského ducha. "41

39 Vladimír Helfert Mirko Očadlíkovi, 26. 7. 1943, strojopisná kopie dopisu uložena v ODH MZM, sine sign.

40 RACEK, op. cit. JIRÁNEK, op. cit.

41 NEJEDLÝ, Zdeněk. Gustav Mahler. In Hudebni sbornik, 1913, roč. 1, s. 2-3. 
Ondřej Pivoda (opivoda@mzm.cz), Ústav hudební vědy, Filozofická fakulta, Masarykova univerzita; Oddělení dějin hudby, Moravské zemské muzeum, Brno.

\section{ABSTRACT \\ ZDENĚK NEJEDLÝ AND VÍTĚZSLAV NOVÁK. A RELATIONSHIP BETWEEN THE CRITIC AND THE COMPOSER}

A musicologist and a historcian Zdeněk Nejedlý aimed his lasting attention to a composer Vítězslav Novák in the first two decades of the 20th century. Nejedlý was dealing with Novák's oeuvre and personality in numerous articles in the newspapers and in the music journals. In 1910 and between 1913-14 he published a comprehensive study in the journal Smetana, where he attempted to grasp critically Novák's artistry. The study was published separately in 1915 and extended into a smaller monography in 1921. A basis for Nejedlý's critical activities was created by a new concept of art criticism by F. X. Šalda (Boje o zitřek, 1905), by Nietzsche's monumentalistic history and by the ideals of the Czech national revival. There was also an important influence of Otakar Hostinský who predetermined Nejedlýs concept of the Czech modern music (especially a polarity between Dvořák and Smetana). Bedřich Smetana and his oeuvre represented a criterion of progressivnes in music for Nejedlý. Analysing Nejedlý's critical statements concerning Novák it attracts particularly Nejedlý's emphasizing of artistic subjectivism on the one hand and his rejecting of exogenous (objective) factors on the other hand (i.e. fundamental rejection of folk music as a base for creation of national music, refusing of musical naturalism, onomatopoeia and illustrativness). The mutual personal disputes affected the relationship between Nejedlý and Novák as well, particularly the so-called „struggless for Dvořák“ after 1912. If and how much these struggles influenced Nejedlý's negative judgements about Novák's compositions (Specter's bride, Zvíkovský rarášek, Karlštejn) remains questionable. In his monography about Novák from 1921 attempts Nejedlý to reconstruct mental experience and states of the composer; he uses empathy, intuition and introspection (methodological probably influenced by Wilhelm Dilthey) what place his methodolgy near to period Einfühlungsästhetik and musical hermeneutics.

\section{Key words}

Zdeněk Nejedlý, Vítězslav Novák, criticism

\section{Bibliography}

Protest. Národní listy, 1912, roč. 52, č. 346 (15. 12. 1912), s. 4.

Úvodem. Smetana, 1910/11, roč. 1, č. 1, s. [1].

BARTOŠ, Josef. F. X. Šalda a snahy mladé české hudební kritiky. Smetana, 1913/14, roč. 4, č. 1, S. 5-9.

ČERNÝ, Miroslav K.: Historismus a Nejedlého koncepce muzikologie. Hudební věda, 1977, roč. 14 , č. 1 , s. 52-71.

FUKAČ, Jiř́i. Leoš Janáček a Zdeněk Nejedlý (K problematice vztahu české kritiky k tvorbě počátku 20. století). In Sbornik praci filosofické fakulty Brněnské university, 1963, roč. 12, s. 5-29.

HANZAL, Josef: Vědecká metoda a umělecké tvưrčí postupy v českém dějepisectví, In Zdeněk Nejedlý: Doba - život - dílo, Praha: Ústav pro českou a světovou literaturu ČSAV, 1975, s. 35-69.

HELFERT, Vladimír. Hudební věda a naše hudební poměry. Smetana, 1910/11, roč. 1, č. 1, s. 4-5. HELFERT, Vladimír. Konce hudebního naturalismu: (Vítězslava Nováka Svatební košile). Česká kultura: Kritický list umělecký a vědecký, 1913/14, roč. 2, č. 6, s. 97-100.

JANÁČEK, Leoš. Letnice 1910 v Praze. Hlidka, 1910, roč. 27, s. 555 - 560, 640-644. 
JAUSS, Hans Robert. Dějiny literatury jako výzva literární vědě. In Čtenár jako výzva: Výbor z praci kostnické školy recepčni estetiky. Brno: Host, 2001, s. 7-38.

JIRÁNEK, Jaroslav: Zdeněk Nejedlý - zakladatel české hudební vědy, In Z bojů o českou hudební kulturu. 1. vyd. Praha: Academia, 1979, s. 13-28.

KŘESŤAN, Jiří: Zdeněk Nejedlý: Politik a vědec v osamění, Praha 2012.

NEJEDLÝ, Zdeněk. Boj o Dvořáka: II. Personalie. Smetana, 1912/13, roč. 3, č. 9-10, s. 103-105.

NEJEDLÝ, Zdeněk. Dějiny české hudby. V Praze: Hejda \& Tuček, s. a. [1903].

NEJEDLÝ, Zdeněk. Gustav Mahler. In Hudebni sbornik, 1913, roč. 1, s. 1-38.

NEJEDLÝ, Zdeněk. Jubilejní koncerty konservatoře. Smetana, 1910/11, roč. 1, č. 17-18,s. 271275.

NEJEDLÝ, Zdeněk. Kritiky: (Den 1907-1909). 1. vyd. SNKLHU. Praha: Státní nakladatelství krásné literatury, hudby a umění, 1954, $610 \mathrm{~s}$.

NEJEDLÝ, Zdeněk. K revisi hudebního impressionismu. Smetana, 1915/16, roč. 6, č. 9-10, s. 130136.

NEJEDLÝ, Zdeněk. Novákův „Pan“. Smetana, 1910/11, roč. 1, č. 9, s. 143-144.

NEJEDLÝ, Zdeněk: Vitězslav Novák: Část první, Praha: nákladem časopisu „Smetana“, 1915, 66 s.

NEJEDLÝ, Zdeněk: Vitězslav Novák: Studie a kritiky, Praha: Melantrich, 1921, 239 s.

NEJEDLÝ, Zdeněk. Vítězslava Nováka „Zvíkovský rarášek“. Smetana, 1915/16, roč. 6, č. 1, s. 1-5.

NEJEDLÝ, Zdeněk. Vitězslava Nováka „Karlštejn“. V Praze: Nákladem časopisu „Smetana“, 1916.

NEJEDLÝ, Zdeněk. Z hudebního života: Vítězslav Novák. Smetana, 1911/12, roč. 2, č. 1, s. 15-16.

NEJEDLÝ, Zdeněk: Zdenko Fibich: Zakladatel scénického melodramatu, Praha: Hejda \& Tuček, 1901.

NOVÁK, Vítězslav. O sobě a o jiných. 1. vyd. Praha: Editio Supraphon, 1970

NOVÁK, Vítězslav. Svatební košile. Hudební revue, 1913/14, roč. 7, č. 2, s. 61-67.

NOVÁK, Vítězslav. Z hudebního života. Hudebni revue, 1911, roč. 4, č. 7, s. 396.

RACEK, Jan. O hudebně-vědecké metodě Zd. Nejedlého. Index, 1929, č. 6, s. 7, č. 7, s. 7

STŘÍTECKÝ, Jaroslav - HANZAL, Josef: Předmluva, In NEJEDLÝ, Zdeněk: Uměni staré a nové. Výbor ze studií, Praha: Editio Supraphon 1978, s. 5-37.

ŠALDA, F. X.. Boje o zitřek: Meditace a rapsodie 1898-1904. 6. vyd., Praha: Melantrich, 1948.

VOLEK, Jaroslav. Vítězslav Novák - „osová“ osobnost české moderní hudby. In VOLEK, Jaroslav. Struktura a osobnosti hudby. Praha: Panton, 1988, s. 224-242.

VYCPÁLEK, Ladislav. Jak se pan prof. Nejedlý učil harmonii. Hudebni revue, 1911, roč. 4, č. 7 , s. $379-380$. 